\title{
HUMAN CAPITAL AS THE MAJOR FINANCING IN THE WELFARE STATE
}

\begin{abstract}
Human capital is becoming one of the main types of capital in the global economy. But as any other capital it needs investments. The system of higher education, as well as health care and social security, represents the major investment in the development of human capital. The latter, in turn, is the basis of innovation and economic development of states, nations and intergovernmental alliances. Various research has shown that higher education greatly increases the person's and the country's income in general. Human capital produces new knowledge, which is the key for the future. As a result, the funding of the human capital development, for which the country is mostly responsible, becomes of strategic importance.
\end{abstract}

Key words: human capital, economic development, health care, higher education, innovation, investments, social security.

\section{Introduction}

The experience of highly-developed countries is the convincing example of the evolution and the switch from the system of management to the system of education and science. In early $20^{\text {th }}$ century Ukrainian scientist V. Vernadskiy underlined the role of human intelligence as the production force of global importance, connecting the further development of mankind with science, intelligence and humanism.

Some researchers consider the evolution of the political economy of capitalism to cover the following stages: goods-based economy (the main part of the surplus value is that from goods); relations-based economy (the surplus value is generated at the level of economic project); management-based economy (the main assets of the company - the quality of management); services-based economy (the surplus value is created owing to better service to the customer), and finally, knowledge-based economy, which is based on the intellectual capabilities

Natalia Konstantiuk, PhD, Associate Professor at Ternopil Ivan Pul'uj National Technical University, Ukraine, e-mail: nataliyavatsyk@gmail.com 
of a person, where the surplus value is created during generation and industrial application of knowledge. The creation of value, which, as a political-economic category, becomes non-material in the knowledge-based economy, is connected with the drastic changes in the society and in the business management models (Polunyev Y., 2005).

\section{Financing of human capital}

2.1 Investment in human capital through education and research.

In early $20^{\text {th }}$ century the concept of knowledge as the source of economic development caused the appearance of a new notion of "knowledge-based economy". Knowledge (not so much the philosophic category, but the economic one) is becoming the major source of wealth of nations in the companies and countries. In the developed countries the amount of companies and institutions' industrial assets is closely connected with their ability to generate new knowledge, intellectual capital.

Knowledge-based economy is promoted by its production, distribution and application. The source of economic growth and competitiveness is the production of ideas, but not goods. These are countries, which produce knowledge and integrate it in their economic models, which can be competitive globally. According to the statement of Organization for Economic Cooperation and Development (OECD) knowledge is considered to contribute to labour efficiency and economic growth.

The characteristic features of the economy which is based on the application of knowledge-based factors is the prevalence of high-tech branches and intellectual services in the structure of gross domestic product, creation of the majority of the national income owing to the innovation or technological rent, high level of the companies' capitalization, the main value of which is created owing to non-material assets, that is, the intellectual component.

Knowledge-based economy is becoming the base and the main component of "innovation economy". Its fundamental basis is productive knowledge and proper education, which characterizes the ability to apply human-intellectual capital in the production activity outcomes.

The main difference between the "knowledge-based economy" and the socalled "goods-based economy" is that of continuous technological improvement of the production and self-reproduction of its knowledge factors, not their disintegration in the process of economic exchange, but their quick renovation and relative availability to be applied.

The balance between the knowledge and resources has shifted considerably towards the first one, so that the knowledge has become one of the major factors 
in evaluating the living standards - more important than land, equipment or labour. Nowadays the most technologically developed economies are based on knowledge.

During the last 200 years neo-classic economics determined only two factors of production: labour and capital. Now it is different. Knowledge strengthens capital and energy, having become the main asset of welfare, similar to those of capital and energy, which have changed the land and labour 200 years ago. Moreover, technological developments of the $20^{\text {th }}$ century have changed the main professions, which provide welfare, from those based on physical labour to those "based on knowledge". Technologies and knowledge today are the key factors of production.

Knowledge-based economy treats the country and the company (more locally) as those, which are able to work with their knowledge, that is, to manage them. The management of knowledge can be treated as the processes:

- generation of knowledge - individual and team training in general;

- generalization of knowledge - development of rules, principles and methods of management:

- $\quad$ storing of knowledge - introduction of knowledge in the activity of the company;

- diffusion of knowledge - spreading of knowledge within the company and its limitation outside it;

- coordination and estimation of knowledge - to be certain that various types of knowledge are applied in practice not contradicting each other;

- improvement of knowledge - broadening of knowledge, getting rid of those out-of-date.

In the system of the knowledge-based economy education plays the most important role as the source of intellectual capital and innovation potential of the nation, the sphere of the total adaptation of the society to a paradigm of socio-cultural changes and the main way of acquiring social skills and qualification individually. Education, training of stuff, and the development of creativity are the main directions of the human capital formation, which is the source of strategic competitiveness and social profit in the future.

In a modern society education is becoming the element of the economic growth strategy. Sufficient stimulus for the development of this sphere of activity has become the recognition and propagation of the human capital theory and, as a result, the education has not been treated as one of the types of the non-profitable consumption yet, but as the investment in human capital, which not only contributes to the direct economic and outside social advantages, but promote the economic growth. Now, let us compare the expenses for education in the member countries of the OECD and Ukraine. 
Table 1: Expenses for education in absolute values, 2011*

\begin{tabular}{|c|c|c|c|c|c|c|c|}
\hline \multirow[t]{2}{*}{ Country } & \multirow[t]{2}{*}{$\begin{array}{l}\text { Amount } \\
\text { of GDP, } \\
\text { billions of } \\
\text { doll }\end{array}$} & \multicolumn{2}{|c|}{$\begin{array}{l}\text { Expenses for education } \\
\text { as a part of GDP, } \%\end{array}$} & \multicolumn{2}{|c|}{$\begin{array}{l}\text { Expenses for education } \\
\text { in absolute values, } \\
\text { billions of doll. }\end{array}$} & \multicolumn{2}{|c|}{$\begin{array}{l}\text { Expenses for education } \\
\text { in absolute values, } \\
\text { per } 10 \text { thousand of } \\
\text { population, thousands } \\
\text { of doll. }\end{array}$} \\
\hline & & $\begin{array}{c}\text { All } \\
\text { education }\end{array}$ & $\begin{array}{c}\text { Higher } \\
\text { education }\end{array}$ & $\begin{array}{c}\text { All } \\
\text { education }\end{array}$ & $\begin{array}{l}\text { Higher } \\
\text { education }\end{array}$ & $\begin{array}{c}\text { All } \\
\text { education }\end{array}$ & $\begin{array}{c}\text { Higher } \\
\text { education }\end{array}$ \\
\hline USA & 14991 & 7,3 & 2,6 & 1094,3 & 389,8 & 34867 & 12420 \\
\hline Germany & 3604 & 5,3 & 1,3 & 191,01 & 46,85 & 23493 & 5762 \\
\hline France & 2776 & 6,3 & 1,5 & 174,9 & 41,6 & 26773 & 6368 \\
\hline United Kingdom & 2429 & 6,0 & 1,3 & 145,74 & 31,6 & 23116 & 5012 \\
\hline Canada & 1737 & 6,1 & 2,5 & 109,96 & 43,43 & 32058 & 12662 \\
\hline Australia & 1515 & 6,0 & 1,6 & 90,9 & 24,24 & 41289 & 11010 \\
\hline Korea & 1116 & 8,0 & 2,6 & 89,28 & 29,02 & 18272 & 5939 \\
\hline Sweden & 539 & 6,7 & 1,8 & 36,11 & 9,7 & 39665 & 10655 \\
\hline Belgium & 514 & 6,7 & 1,5 & 34,44 & 7,71 & 32994 & 7386 \\
\hline Austria & 418 & 5,9 & 1,4 & 24,66 & 5,85 & 29392 & 7973 \\
\hline Denmark & 332 & 7,9 & 1,9 & 26,23 & 6,31 & 47317 & 11383 \\
\hline Finland & 263 & 6,4 & 1,9 & 16,83 & 5,0 & 31978 & 9500 \\
\hline Ireland & 221 & 6,3 & 1,6 & 13,92 & 3,54 & 29479 & 7497 \\
\hline New Zealand & 163 & 7,4 & 1,6 & 12,06 & 2,61 & 27865 & 6031 \\
\hline Ukraine & 161 & 8,1 & 1,16 & 13,04 & 1,87 & 2862 & 410 \\
\hline
\end{tabular}

${ }^{\star}$ Compiled by the author, and based on Education at a Glance 2012

As it is seen from Table 1, the financing of education in Ukraine, higher education in particular, leaves much to be desired. Although, relating to GDP the value is rather high $(8,1 \%)$, in terms of money the expenses for education are 13 billion dollars, 1,87 billion dollars for higher education in particular. If the expenses for 10000 inhabitants are taken into account, the result is not comforting. Ukraine spends for education 2862 thousand of dollars in total, 410 thousand of dollars for higher education. If we compare general expenses for education for 10000 inhabitants, they are 10 times higher in Austria, Ireland, Belgium, New Zealand, and 15-20 times higher in Denmark, Australia, Canada, Sweden, USA. The largest expenses for education are in Canada, Australia, Sweden, and Denmark. Those are the countries which are the world leaders in economic and social development and their expenses for education can be treated as the strategic investment in the economy of their country. 
Such investments in the sphere of education have proved to be correct, because the reversible effect is seen. These are the countries which have the highest GDP in the world. That is, the investments in education are justified for both the country and the individual, and the rates of profit are different for different countries, which is testified by the data on Table 2 .

Table 2: Profit rate for a person with University degree*

\begin{tabular}{|c|c|c|c|c|}
\hline \multirow[t]{2}{*}{ Country } & \multicolumn{2}{|c|}{$\begin{array}{l}\text { Profit rate, when a person took } \\
\text { University degree after completion of } \\
\text { the secondary school, } \%\end{array}$} & \multicolumn{2}{|c|}{$\begin{array}{l}\text { Profit rate, when a person took } \\
\text { University degree at the age of } 40, \%\end{array}$} \\
\hline & for the state & for the person & for the state & for the person \\
\hline Belgium & 15,0 & 12,98 & 10,0 & 24,08 \\
\hline United Kingdom & 14,9 & 18,21 & 7,4 & 13,16 \\
\hline Denmark & 7,4 & 8,21 & 2,2 & 11,30 \\
\hline Korea & 15,5 & 13,56 & 12,3 & 21,34 \\
\hline Norway & 9,7 & 13,89 & 4,4 & 15,77 \\
\hline USA & 13,6 & 13,73 & 7,8 & 11,33 \\
\hline Hungary & 15,9 & 18,79 & 12,5 & 22,23 \\
\hline Finland & 12,4 & 16,33 & 9,7 & 14,74 \\
\hline Switzerland & 6,1 & 9,90 & $-0,4$ & 15,77 \\
\hline Sweden & 6,9 & 8,57 & 2,7 & 9,33 \\
\hline
\end{tabular}

*Compiled by the author and based on (Education at a Glance 2012)

When analyzing the data from Table 2 it should be stressed that the profit rate from the investments in education is high enough for both the country and the individual. In some cases it exceeds the average profit rate for the industrial enterprises. Such type of investment is reasonable in all aspects, as it always contributes to economic and social advantages.

Knowledge, as the result of educational activity, is transformed into technologies and products of the science-based production; it promotes the increase of labour efficiency, decreases the material and energy-consuming, raises the competitiveness of the social production, accelerates the rate of accumulation of the social profit, changing the motivation of the labour activity, thus being the factor of post-industrial economic growth. Intellectual capital is able to bring the highest economic output for every unit of additional investment, providing not only the high profitability of the production and reliable competitive advantage in the world markets, but creating the background of the strategic profit for innovative investments. 
The balance between knowledge and resources has been replaced towards the first one, so that the knowledge has become one of the most important factors for evaluating the living standards, more important than land, equipment and labour. Nowadays the most technologically developed economies are totally based on knowledge.

It must be stressed that the UN has defined the level and the quality of education as the factors of the development of human potential, which provides social-economic progress of the society as a whole. That is why highly-developed countries increasingly invest into their education, as it provides the creation of not only intellectual, but humanitarian potential of the nation. The latter is characterized by the level of psychological and physical health of the nation, its social welfare, moral and spiritual strength, intellectual development, psychological unity and humanitarian activity. It is humanitarian potential, which contributes to wealthy and successful society.

Education has always had and will have the impact on the progress in economy of any state and the society as a whole. With the development of the economic science education becomes of greater importance and is treated as the compulsory component of the intellectually-developed state and society.

\subsection{The importance of social security in financing of human capital.}

Human capital as a special type of capital needs a proper social protection. In the broad sense social protection is treated in literature as the activity of the state to apply in life the challenges and major tasks of social policy, to realize the complex of legally adopted economic and social guarantees, which provide every member of the society with the most important social rights irrespective of their sex, nationality, age, area of living, etc. In its narrower sense the social protection is the complex of purposeful means of economic, legal and organizational type, directed to provide the rights and guarantees of a person in their living standards in order to support mostly those, who are in need.

Financial support of social protection is carried out in two ways: social donations or taxes, which vary in different countries. Special attention to the financial support of social protection is paid by the countries of the OECD-members. 
Figure 1: Financial support of social protection of population in \% of GDP*

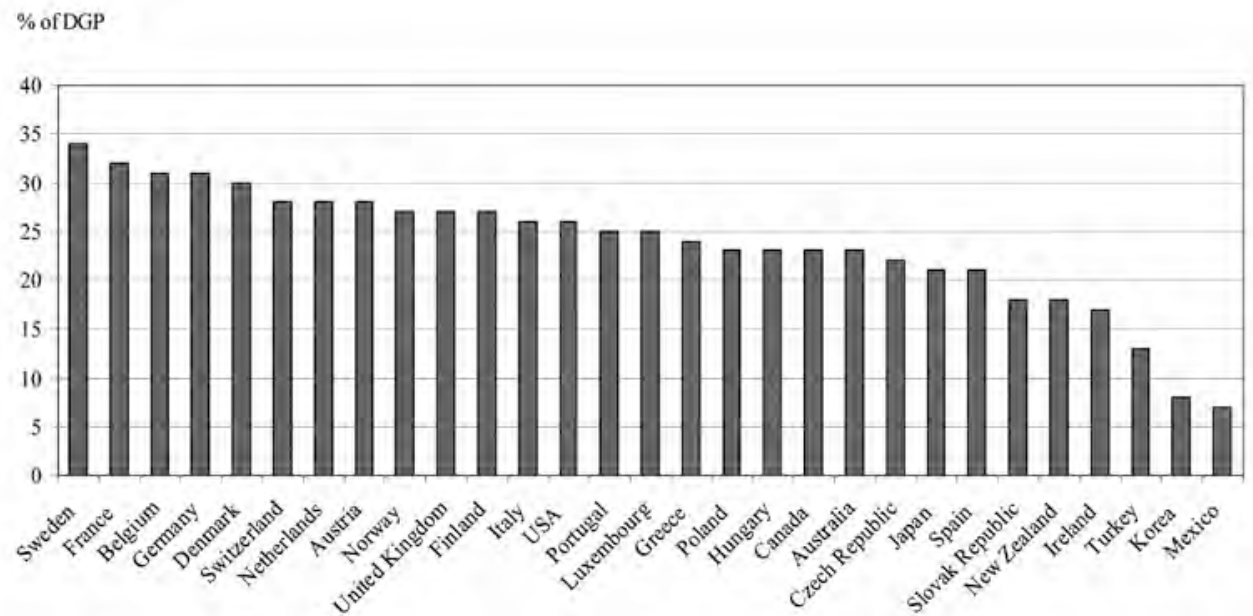

${ }^{*}$ Compiled by the author, based on OECD Social Expenditure database (SOCX).

As it is seen from Fig. 1 the best financing of social protection is in Sweden, where these expenses are $34 \%$ of GDP. The expenses in France, Belgium, Germany, Denmark are high enough, where they make 30-32 \% of GDP. The expenses for social protection in such countries as Switzerland, Netherlands, Austria, Norway, Great Britain, Finland, Italy, USA, Portugal, Luxembourg are within 25-28\%. Somewhat lower are the expenses in Ireland, New Zealand, Slovak Republic, Spain, Japan, Czech Republic, Australia, Canada, Hungary, Poland, Greece, within 17-24 \% of GDP. The lowest expenses are in Mexico, Korea, Turkey, within 7-13\% of GDP. As for Ukraine, the expenses for social protection and social support of population were only $8 \%$ of GDP in 2011 (Statistical Journal). That is, the lower values are only in Mexico.

For the last decades sufficient growth has taken place in the OECD-member countries, which is characterized by the raise of the living standard and conditions of work, and improvements in the sphere of health care and education. But not only can the material goods contribute to the welfare in the world. The level of absolute poverty has decreased in the OECD-member countries since 1950. Economic growth is not only aimed at that, it provides the resource for solving the problems of social isolation, poverty, social protection.

The presented data proves to confirm that the developed countries have already realized the importance of the development of human capital, and all expenses for it are treated as investments in the development of the society, economy of the country, etc. 
2.3. Health care as an important component of human capital investments.

Investments in human capital are provided through the system of health care and the like, which make it possible for people to be more efficient economically.

Economists, demographers, and politicians have been discussing the interrelation between the system of health care and economic welfare for a long time. The research has shown that in a poorly developed system of health care, its insufficient financing results in the age structure of the population of the country, in which retired people are the major part.

Rising of the effectiveness of the health care system contributes to the increase of income and accumulation of assets on both the house-keeping level and the state in general. It should be noted that healthy people work better and are physically and mentally stronger, that is, they are likely to be more efficient while gaining their income. Healthy people have longer life-span, thus having more possibilities to obtain economic advantages from the investments in human capital.

Improvement of health results in greater life-span which contributes to higher personal savings of people. The increase of savings of the population decreases the impact on the system of social pension maintenance and creates additional financial funds, which can be used for the further investments and assets accumulation.

The study of some research testified that the improvement of health is connected with high income. Healthy people have income 10-13\% higher than those with worse health. Families who take care of their health, produce higher assets by $25 \%$ than those who do not take care of their health. It makes possible to transform the greater part of these assets into savings, jewelry items, real estate and long-term consuming goods, which can be used in the future for the financial support and social maintenance of retired people (reproductive health and economic development).

Better availability of the health care services can promote the economic development and help some people and families to get rid of poverty. There is plenty of research which proves the direct connection between the system of health care and the economic growth of the society.

Thus, we can conclude that there exists a close interrelation between the health of the nation and the economic development, welfare and wealth of the country. If one wants to take advantage of this situation, the country and its population must invest primarily in the field of the health care, which, as the result, will increase the profitability (efficiency) of human capital.

In Table 3 the expenses for health care in some countries are presented. 
Table 3: Expenses for health care in percents of GDP (World Bank)

\begin{tabular}{|c|c|c|c|c|}
\hline Country & 2008 & 2009 & 2010 & 2011 \\
\hline Australia & 8.8 & 9.0 & 9.0 & 9.0 \\
\hline Austria & 10.5 & 11.1 & 11.0 & 10.6 \\
\hline Belarus & 5.9 & 6.1 & 5.6 & 5.3 \\
\hline Belgium & 10.0 & 10.7 & 10.5 & 10.6 \\
\hline Brazil & 8.3 & 8.8 & 9.0 & 8.9 \\
\hline Bulgaria & 7.0 & 7.2 & 7.6 & 7.3 \\
\hline Canada & 10.3 & 11.4 & 11.4 & 11.2 \\
\hline Costa Rica & 9.3 & 10.3 & 10.3 & 10.9 \\
\hline Croatia & 7.8 & 7.8 & 7.8 & 7.8 \\
\hline Cuba & 10.8 & 11.7 & 10.2 & 10.0 \\
\hline Cyprus & 6.9 & 7.2 & 7.4 & 7.4 \\
\hline Czech Republic & 6.8 & 8.0 & 7.5 & 7.4 \\
\hline Denmark & 10.2 & 11.5 & 11.1 & 11.2 \\
\hline Finland & 8.3 & 9.2 & 9.0 & 8.9 \\
\hline France & 11.0 & 11.7 & 11.7 & 11.6 \\
\hline Georgia & 9.0 & 10.2 & 10.2 & 9.9 \\
\hline Germany & 10.7 & 11.7 & 11.5 & 11.1 \\
\hline Greece & 10.9 & 11.2 & 10.8 & 10.8 \\
\hline Hungary & 7.5 & 7.7 & 7.8 & 7.7 \\
\hline Iceland & 9.1 & 9.6 & 9.3 & 9.1 \\
\hline India & 3.9 & 3.9 & 3.7 & 3.9 \\
\hline Indonesia & 2.8 & 2.9 & 2.8 & 2.7 \\
\hline Iran, Islamic Rep. & 5.8 & 5.8 & 5.3 & 6.0 \\
\hline Iraq & 4.9 & 8.5 & 8.5 & 8.3 \\
\hline Ireland & 8.8 & 9.4 & 9.2 & 9.4 \\
\hline Israel & 7.7 & 7.7 & 7.7 & 7.7 \\
\hline Italy & 9.0 & 9.5 & 9.5 & 9.5 \\
\hline Jamaica & 5.3 & 5.0 & 5.2 & 4.9 \\
\hline Japan & 8.6 & 9.5 & 9.2 & 9.3 \\
\hline Latvia & 6.6 & 6.8 & 6.7 & 6.2 \\
\hline Lithuania & 6.6 & 7.5 & 7.0 & 6.6 \\
\hline Luxembourg & 7.2 & 8.2 & 7.9 & 7.7 \\
\hline Marshall Islands & 18.8 & 18.9 & 17.1 & 16.5 \\
\hline Mexico & 5.8 & 6.4 & 6.3 & 6.2 \\
\hline Moldova & 11.4 & 12.5 & 11.7 & 11.4 \\
\hline Monaco & 3.6 & 4.2 & 4.4 & 4.4 \\
\hline Netherlands & 11.0 & 12.0 & 12.1 & 12.0 \\
\hline New Zealand & 9.3 & 10.0 & 10.1 & 10.1 \\
\hline Norway & 8.6 & 9.7 & 9.3 & 9.1 \\
\hline Poland & 6.9 & 7.2 & 7.0 & 6.7 \\
\hline
\end{tabular}


Nataliia Konstantiuk

\begin{tabular}{|l|c|c|c|c|}
\hline Portugal & 10.2 & 10.8 & 10.7 & 10.4 \\
\hline Romania & 5.4 & 5.6 & 5.9 & 5.8 \\
\hline Russian Federation & 5.1 & 6.2 & 6.5 & 6.2 \\
\hline Serbia & 10.4 & 10.5 & 10.4 & 10.4 \\
\hline Slovak Republic & 8.0 & 9.2 & 9.0 & 8.7 \\
\hline Slovenia & 8.3 & 9.2 & 9.0 & 9.1 \\
\hline Spain & 8.9 & 9.6 & 9.6 & 9.4 \\
\hline Sweden & 9.2 & 9.9 & 9.6 & 9.4 \\
\hline Ukraine & 6.6 & 7.8 & 7.8 & 7.2 \\
\hline United Kingdom & 8.7 & 9.7 & 9.6 & 9.3 \\
\hline United States & 16.6 & 17.7 & 17.6 & 17.9 \\
\hline
\end{tabular}

As it is seen from Table 3 the highest expenses for health care are in the USA, $17,9 \%$ from GDP in 2011. Then follow the countries where expenses are more than $10 \%$ : Austria, Belgium, Denmark, France, Germany, Greece, Netherlands, Portugal, Serbia, Switzerland. The expenses in Canada, New Zealand, Australia, Norway, Costa Rica, Cuba, Finland, Georgia, Ireland, Iceland, Italy, Japan, Moldova, Slovenia, Sweden are also high enough, and make 9-10\% of GDP.

Expenses for health care in Ukraine were 7,2 \% of GDP in 2011, two years ago they were $7,8 \%$. That means that its amount decreases. Financing of the health care system is sufficiently lower than in economically developed countries. Besides, if we take into account the absolute expenses for its financing, they will be lower because of the constant drop of GDP during the previous years.

According to the survey of the Institute of sociology of NASU (National Academy of Sciences of Ukraine) the most required needs and the least provided are those in the health care $-51,3 \%$; moreover, $58,8 \%$ of population feel the lack of health care, $43,6 \%$ - lack of good stuff, $40,9 \%$ - lack of good housing conditions.

According to the experts' survey of the International Organization of Health Care (IOHC), when the expenses for the health care are lower than $5 \%$ of the GDP, the economy becomes ineffective.

The health of a nation is the major condition of the economic prosperity. It impacts greatly the economic results from the point of view of labour efficiency, labour power, human capital and the expenses of the state.

Thus, to increase the welfare of people and to raise the economy of the country it is necessary to improve the level of effectiveness of the system of health care and its availability. 


\section{Human capital as the key of future success of nations, states and the world}

The concept of human capital as it is treated now, is the natural result of the world economic and philosophic thought. Foremost, it is connected with the development of the capital conception. V. Petty was the first to bring the idea that people together with their production abilities are the wealth themselves.

The theory of human capital studies the dependence between the enterprise worker and the state income, and knowledge and the skills of this worker. The first to prove this dependence was Adam Smith. In his main paper "Investigations on the origin and reasons of the people's wealth" he wrote that it is a worker, his skills and abilities, which produce wealth. The growth of the useful labour efficiency depends, foremost, on the raising of their capability and efficient management, and only then on the improvement of machines and instruments he works with. D. Ricardo treated the problems in the economic development as those caused by different reasons, "insufficient education of all levels of population" being one of them.

The theory of capital by I. Fisher has become the background for the appearance of different alternative conceptions of human capital. Their authors do not only include knowledge and skills of people in the notion of "human capital", not only their ability to work, but their physical, psychological, social and cultural properties and capabilities.

In the second part of the $20^{\text {th }}$ century the theory of human capital started to develop rapidly and became an independent field of the world economic thought owing to the works of the American scientists Harry Backer, Jacob Mincer, Theodor Schults, etc. T. Schults was the first to publish his complex works on the theory of human capital: "Formation of the education capital" (1960) and "Investments in human capital" (1961).

From the point of view of human capital, the income of people is the natural result of decisions made earlier. That is, when a person makes a decision, they can directly influence the amount of their future income. Future income can be increased greatly while investing in your own education and professional training, your health, culture, increasing by it your own (private) human capital.

Thus, the country wishing to provide its stable economic growth must provide the proper development of human capital, which becomes the major factor of the development of the economy at the modern stage. Provision of the development of human capital is possible through the investments, which possess some peculiarities that distinguish them from other types of investments:

- investments efficiency in the human capital depends directly on the person themselves, the earlier they have been contributed, the higher their efficiency will be. But another characteristic of the investments 
of human capital is that the most qualitative and constant investments result in higher and continuous outcomes;

- human capital, as any other type of capital, tends to wear out physically and morally, but it can also be accumulated and grow. Accumulation of human capital occurs during continuous training of the worker and accumulation of the production experience by him. If this process is continuous, the qualitative and quantitative characteristics of human capital can be improved and increased;

- while accumulating human capital its profitability increases till certain level, that is, till active able-bodied age, and then decreases sharply;

- as compared with the other forms of capital investments, the investments in human capital are the most profitable both for the individual and the society in whole.

Investments in human capital became the background for the stable economic development in the United States in the late 20th century. It is the United States that possesses the greatest amount of the human capital, which constitutes about three-fourths of all national wealth of the country. The data in Tables 1 , 3 , and in Figure 1 confirm that the USA is the world's leader in the amount of investments in education, health care and social protection of population.

\section{Conclusion}

The raising of living-standard of population of Ukraine must be the major direction of the development of human capital, which can be possible through the improvement of the effectiveness of the system of education functioning and its availability, improvement of health care and social protection. These are the spheres to which the government must pay special attention, providing them with the proper financing, which will result in the economic growth of the country and social welfare.

The government of the country should increase the expenses for these branches, since the increase of expenses for the development of education, health care and social protection means the raise of investments in the development of human capital. It is reasonable to stimulate private investments in the development of human capital using different tax, credit and monetary levers.

While both state and private investments contribute to the development of human capital, it is necessary to change the orientation from short-term to longterm, because it takes more time to obtain the output from the investments in human capital than investing in other forms of capital, i.e. the process of gaining output from these investments takes much more time. 
Investments in education must be done during all the life of people, not only while studying at school or for a university degree. One should study and raise its qualification during all their life, meeting the demands of the market.

Availability of health care, irrespective of the people's income and area of living, must be provided to preserve and strengthen the health of population. It is reasonable to promote healthy way of living, which will result in the decrease of the state expenses for health care.

\section{Literature}

- Dlugopolsky O. V. (2011). Social sector of economy and public finances in the era of global transformations: Monography. Ternopil: Economic thought, TNEU, 632p.

- Elita Jermolajeva, Daina Znotina. Investments in the Human Capital for Sustainable Development of Latvia [Web-resource]. Currently available at: http://www.regionalstudies.org.

- Financing social protection: the employment effect. OECD Employment Outlook. (2007). [Web-resource]. Currently available at: http://www.oecd. org/els/emp/40776791.pdf.

- Grishnova O. A. (2001). Human capital: forming in the system of education and professional training. K.: Society 'Znannya", KOO, 254p.

- Health expenditure, total (\% of GDP). (2011). [Web-resource]. Currently available at: http://data.worldbank.org/indicator/SH.XPD.TOTL.ZS

- Kholod. N. M. (2009). Distribution of incomes and poverty in the transforming economics (monography). Lviv: Publishing center of the Lviv Ivan Franko National University, 442p.

- OECD (2012), Education at a Glance 2012: OECD Indicators, OECD Publishing. http://dx.doi.org/10.1787/eag-2012-en

- Polunyev Y. Agnitio est prosperitas: from the goods economy to the knowledge economy. Dzerkalo Tyzhnya. № 19, 2005.

- Shareen Joshi (January, 2012). Reproductive health and economic development: what connections should we focus on? [Web-resource]. Currently available at: http://www.prb.org.

- Social Protection of population of Ukraine. Statistical Yearbook. (2012). Kyiv, 119p.

- The experience of European countries in financing health care: lessons for Ukraine. 2002, 101p. [Web-resource]. Currently available at: http:/ /eeas. europa.eu/delegations/ukraine/documents/virtual_library/14_reviewbook_uk.pdf

- Vakhovych I. Financial maintenance of higher education: methodology and mechanism of realization while forming social-oriented market 
economy: [Monography] / I. Vakhovych, Y. Volynchuk. - Lutsk: PBB LNTU, 2010. - 288p.

- World Development Report 2007: Development and the Next Generation. - World Bank, 2007. - 336 p. [Web-resource]. Currently available at: http://data.worldbank.org.

Paper received: November $29^{\text {th }}, 2013$

Rad primljen: 29. novembar 2013.

Approved for publication: February $28^{\text {th }}, 2013$ Odobren za štampu: 28. februar 2013. 


\section{Dr Natalija Konstantijuk, vanredni profesor}

Ternopilski nacionalni tehnički univerzitet „Ivan Puljuj“, Ukrajina

\section{LJUDSKI KAPITAL KAO GLAVNA INVESTICIJA U DRŽAVI BLAGOSTANJA}

\section{S a ž e t a k}

Ljudski kapital postaje jedan od glavnih tipova kapitala u globalnoj ekonomiji. Ali, kao i svaki drugi kapital, i njemu su potrebna ulaganja. Sistem visokog obrazovanja, kao i zdravstvenog osiguranja i socijalne zaštite, glavna je investicija u razvoju ljudskog kapitala. Ovo je pak, sa svoje strane, osnova inovacija i ekonomskog razvoja država, nacija i međuvladinih saveza. Mnoga istraživanja su pokazala da visoko obrazovanje u velikoj meri povećava prihode pojedinca i države u celini. Ljudski kapital proizvodi nova znanja, što je ključ za budućnost. Kao rezultat toga, finansiranje razvoja ljudskog kapitala, za koje je država uglavnom odgovorna, postaje od strateškog značaja.

Ključne reči: ljudski kapital, ekonomski razvoj, zdravstveno osiguranje, visoko obrazovanje, inovacije, investicije, društvena zaštita 